\title{
Functional Analysis of Fibroblastic Reticular Cells Derived from Mouse Lymph Node via Bidirectional Crosstalk with T Cells
}

\author{
Sung Hee Park ${ }^{1}$ and Jong-Hwan Lee ${ }^{1,2_{\star}}$ \\ ${ }^{1}$ Department of Biotechnology and Bioengineering, Dong-Eui University, Busan 614-714, Korea \\ ${ }^{2}$ Department of Smart Bio-Health, Dong-Eui University, Busan 614-714, Korea
}

Received July 25, 2013 /Revised September 14, 2013 /Accepted October 1, 2013

\begin{abstract}
Fibroblastic reticular cells (FRCs) form the structural backbone of the $\mathrm{T}$ zone provide a guidance path for immigrating $\mathrm{T}$ cells in the lymph node (LN). FRCs may contribute directly to developing T-cell biology in the LN and allow analyses of fundamental aspects of FRC biology related to T cells. FRCs inhibited T-cell apoptosis, and FRC culture supernatants strongly induced the expression of Bcl-xL in $\mathrm{T}$ cells against doxorubicin. Coculture of FRC and T cells resulted in rearrangements of the actin cytoskeleton, as well as global changes in the morphology of the FRCs. In addition, when cocultured, the $\mathrm{T}$ cells adhered to the FRC monolayer, and the membrane intercellular adhesion molecule (ICAM)-1 was slightly increased by day-dependent manner. In contrast, the expression of soluble ICAM-1 was dramatically increased in a day-dependent manner. Several chemokines, such as CCL5, CXCL1, CXCL5, CXCL16, CCL8, CXCL13, and ICAM-1, and MMPs were expressed in FRCs sensed by tumor necrosis factor (TNF) families. Nuclear factor kappa B (NFkB)-RelA of the NFkB canonical pathway was translocated into FRC nuclear by TNFa. In contrast, p52 proteolyzed from p100, a counterpart of RelB of the noncanonical NFkB pathway, accumulated in the peripheral FRC nucleus by agonistic anti-LTßR antibody. In summary, we propose a model in which FRCs engage in bidirectional crosstalk to increase the efficiency of T-cell biology. This cooperative feedback loop may help to maintain tissue integrity and function during immune responses.
\end{abstract}

Key words : Agonistic anti-LTßR antibody, FRC, NFkB, T cell, TNFa

\section{Introduction}

Immune system is composed of primary lymphoid organs, secondary lymphoid organs (SLO), immune cells, and immune regulation factors. SLO, such as lymph nodes (LN), Peyer's patches and spleen, are critical for efficient start of adaptive immunity. The LN structure provides meeting places where lymphocytes coming from the blood encounter toxic pathogens and their products brought from infected region. LN is partitioned into cortical, paracortical and medullary areas [13, 18]. Moreover, LN contained hematopoietic immune cells and non-hematopoietic stromal cell. The cortical region contains follicles, which include B cells and follicular dendritic cells (FDC) [13], and the paracortical region, which includes $\mathrm{T}$ cells, interdigitating cells, dendritic

\footnotetext{
*Corresponding author

Tel : +82-51-890-2280, Fax : +82-51-890-2632

E-mail : jonghwanlee@deu.ac.kr

This is an Open-Access article distributed under the terms of the Creative Commons Attribution Non-Commercial License (http://creativecommons.org/licenses/by-nc/3.0) which permits unrestricted non-commercial use, distribution, and reproduction in any medium, provided the original work is properly cited.
}

cells, macrophages, fibroblastic reticular cells (FRC). Additionally, non-hematopoietic stromal cells, such as endothelial cells, marginal reticular cell, integrin $a 7^{+}$pericyte and undefined stroma provide a structural framework for the LN through functional signals like chemokines and cytokines $[13,18]$. So far, stromal cells of SLOs have long been recognized as constructor and maintenance players of SLO tertiary architecture environments in each SLO partition $[1,6$, 11]. FRC is thought to be highly specialized to the development of the lymphoid microenvironment. FRC secretes and ensheathes an extracellular matrix (ECM)-based reticular or conduit network within the T-cell zones of LNs [14, 17, 23, 24]. Within the $\mathrm{LN}$, naive $\mathrm{T}$ cells are activated in the FRCrich paracortical region. Accordingly, others were interested in understanding how the presence of FRCs might affect the progression of the T-cell response [16]. In vitro studies have demonstrated that ECM secretion of FRC is dramatically enhanced by the presence of $\mathrm{T}$ cells [24]. It suggests FRC may contribute directly to developing T-cell biology in $\mathrm{LN}$. However, our understanding of these fibroblast subsets is still very limited, and much progress must have been made in defining various functions of FRC related to $\mathrm{T}$ cell 
immunity. Thus, it allows for us to investigate fundamental aspects of FRC biology between FRC and $\mathrm{T}$ cells.

\section{Materials and Methods}

\section{Cell culture}

FRC was established as described previously [14]. FRC was maintained in $10 \%$ fetal calf serum - dulbeco's modified eagle's medium (DMEM) and CD4+ EL4 T lymphoma was cultured in roswell park memorial institute medium (RPMI) 1640 supplement with $10 \%$ FCS supplemented with streptomycin and penicillin.

\section{Antibody}

The antibodies used for immunostaining or Western blot were as follows: as primary reagents, in biotin anti - intercellular adhesion molecule (ICAM)-1 antibody (Immunotech, Monrovia, CA, USA), rabbit anti-Bcl-xL antibody, rabbit anti-RelA (p65) antibody, monoclonal anti-p52 antibody (Santa Cruz Biotechnology, Dallas, Texas, USA), rabbit anti-glyceraldehyde-3-phosphate dehydrogenase (GAPDH) antibody, as secondary reagents, fluorescein isothiocyanate (FITC) anti-mouse IgG antibody, FITC anti - rabbit IgG antibody (Jackson Immuno Research Laboratories, West Grove, PA, USA), horse radish peroxidase (HRP)-anti-rabbit IgG antibody, HRP-streptavidin (Molecular Probes, Eugene, OR, USA). Polyclonal goat agonistic anti-lymphotoxin- $\beta$ receptor (LT $\beta R$ ) antibody against mouse LT $\beta R$ extracellular domain and control IgG for cell stimulation were purchased from R\&D Systems (Minneapolis, MN, USA).

\section{T cell viability cocultured with FRC}

Co-cultures were initiated by seeding FRCs $\left(1 \times 10^{5}\right.$ cells/ dish) onto $6 \phi$ cell culture dish for $12 \mathrm{~h}$ and cocultured with $8 \mu \mathrm{g} / \mathrm{ml}$ Dox-treated CD4+ EL4 T cells $\left(1 \times 10^{6}\right.$ cells/dish $)$ in RPMI1640 medium supplement with 10\% FCS for $24 \mathrm{~h}$. T cells were harvested after $24 \mathrm{~h}$ by pipetting the medium that contained the cells to rule out the presence of FRC, and then centrifuging at 1,500 rpm for $3 \mathrm{~min}$. Following removal of the supernatants (sup), fresh medium was added to the $T$ cell pellets, and then the suspended cell medium was transferred into 96-well plate. Cell viability was determined using CellTiter 96 Aqueous One Solution Reagent (Promega, Madison, WI, US). Cells were placed in 96-well plastic culture plates, and then $100 \mu \mathrm{l}$ of $0.5 \mathrm{mg} / \mathrm{ml}$ tetrazolium compound [3-(4,5-dimethylthiazol-2-yl)-5-(3-carboxymethoxyph-
enyl)-2-(4-sulfophenyl)-2H-tetrazolium (MTS) solution was added to each well and incubated for $4 \mathrm{~h}$ at $37^{\circ} \mathrm{C}[2,4,22]$. Formazan absorbance was read at $490 \mathrm{~nm}$ using a plate reader.

\section{Western blot anakysis}

Cell lysate was extracted in 1\% Nonidet P-40, $120 \mathrm{mM}$ $\mathrm{NaCl}, 50 \mathrm{mM}$ Tris (pH 8.0), $1 \mathrm{mM}$ ethylenediaminetetraacetic acid, $0.1 \mathrm{mM}$ phenylmethylsulfonylfluoride, $10 \mu \mathrm{g} / \mathrm{ml}$ leupeptin and $10 \mu \mathrm{g} / \mathrm{ml}$ aprotinin. For preparing culture sup of FRC, FRC $\left(5 \times 10^{6}\right.$ cells $)$ in $6 \phi$ dish were cultured for 24 $\mathrm{h}$. Then, culture sup were collected, filtered and stored until experiments. T cells $\left(5 \times 10^{6}\right.$ cells) were pretreated with FRC $\sup (100 \mathrm{ng} / \mathrm{ml})$ and incubated for $1 \mathrm{~h}$, and followed by further incubation for $24 \mathrm{~h}$ in the presence or absence of FRC sup and doxorubicin (Dox) $(100 \mu \mathrm{g} / \mathrm{ml}$ ) (Sigma Chemical, St. Louis, MO, USA) for the expression degree of Bcl-xL. To investigate ICAM-1 expression in FRCs, FRC $\left(5 \times 10^{6}\right.$ cells) cocultured with $\mathrm{T}$ cells $\left(5 \times 10^{6}\right.$ cells $)$ was grown on $6 \phi$ dish plate for 1day (D), 2D, and 3D. After coculturing, $\mathrm{T}$ cells were removed out by pipetting the medium that contained the $\mathrm{T}$ cells to rule out the presence of FRC monolayer. The expression degree of membrane bound ICAM-1 (mICAM-1) and soluble ICAM-1 (sICAM-1) was detected by utilizing biotin-anti-ICAM-1 antibody and streptavidin-HRP. GAPDH was used to demonstrate equal loading of lysates. Protein concentration was determined by BCA method. After the samples were boiled, equal amounts of total lysates were separated by SDS-PAGE and transferred onto polyvinylidene difluoride membranes. The membranes were soaked in a blocking solution (5\% skim milk and $0.2 \%$ Tween 20-PBS) for $1 \mathrm{~h}$, and then incubated with polyclonal anti-LTßR antibody for $1 \mathrm{~h}$. After being washed with Tween 20-PBS, membranes were incubated with HRP-conjugated anti-rabbit antibodies for $1 \mathrm{~h}$. Specific bands were visualized by an ECL method $\left(\mathrm{ECL}^{+}\right.$Amersham Biosciences, Piscataway, NJ, USA).

\section{RNA isolation}

Total RNA was isolated by using TRIzol reagent (Invitrogen, Carlsbad, CA, USA). The RNA were extracted with chloroform (Sigma Chemical, St. Louis, MO, USA) and followed by ethanol precipitation. RNA was quantified using NanoDrop®ND-1000 spectrophotometer (NanoDrop Technologies, Inc., Wilmington, DE, USA). And RNA quality was assessed using Agilent RNA Nano 6000 LabChip kits 
and Agilent 2100 Bioanalyzer (Agilent Technologies, Palo Alto, CA, USA).

\section{Microarray analysis}

control and test RNAs, the synthesis of target cRNA probes and hybridization were performed using Agilent's Low RNA Input Linear Amplification kit (Agilent Technology, Santa Clara, CA, USA) according to the manufacturer's instructions. Briefly, each $1 \mathrm{\mu g}$ total RNA and T7 promoter primer mix and incubated at $65^{\circ} \mathrm{C}$ for $10 \mathrm{~min}$. cDNA master mix was prepared and added to the reaction mixer. The samples were incubated at $40^{\circ} \mathrm{C}$ for $2 \mathrm{~h}$ and then the RT and dsDNA synthesis was terminated by incubating at $65^{\circ} \mathrm{C}$ for $15 \mathrm{~min}$. The transcription master mix was prepared as the manufacturer's protocol (4X Transcription buffer, $0.1 \mathrm{M}$ DTT, NTP mix, 50\% PEG, RNase-Out, Inorganic pyrophosphatase, T7-RNA polymerase, and Cyanine 3/5-CTP). Transcription of dsDNA was performed by adding the transcription master mix to the dsDNA reaction samples and incubating at $40^{\circ} \mathrm{C}$ for $2 \mathrm{~h}$. After purification, labeling, fragmentation and assembling onto Agilent's Mouse Oligo Microarray (44K) of cRNA the arrays hybridized at $65^{\circ} \mathrm{C}$ for $17 \mathrm{~h}$ using Agilent Hybridization oven (Agilent Technology, Santa Clara, CA, USA). The hybridized microarrays were washed as the manufacturer's washing protocol (Agilent Technology, Santa Clara, CA, USA). The hybridized images were scanned using Agilent's DNA microarray scanner and quantified with Feature Extraction Software (Agilent Technology, Santa Clara, CA, USA). All data normalization and selection of fold-changed genes were performed using GeneSpringGX 7.3 (Agilent Technology, Santa Clara, CA, USA). The averages of normalized ratios were calculated by dividing the average of normalized signal channel intensity by the average of normalized control channel intensity.

\section{Fluorescence staining}

FRC monolayers on chamber slides were cocultured with CD4+EL4 T cells for $24 \mathrm{~h}$. Cells were stained with rodamine phalliodin $(5 \mu \mathrm{g} / \mathrm{ml})$ (Cell Signaling Technology, Danvers, MA, USA) for $45 \mathrm{~min}$ to observe changes in F-actin distribution after fixation and washing, and examined by Zeiss photomicroscope equipped for fluorescence microscopy. Nuclear was stained with 4'-6-Diamidino-2-phenylindole (DAPI) (Invitrogen, Carlsbad, CA, USA). FRC monolayers grown on chamber slides were treated with tumor necrosis factor a (TNFa) $(100 \mathrm{ng} / \mathrm{ml})$, and agonistic anti-LTßR anti- body $(1 \mu \mathrm{g} / \mathrm{ml})$ for $6 \mathrm{~h}$ in FRC. Cells were stained with anti-p65 antibody for canonical pathway and anti-p52 antibody for noncanonical pathway after fixation, permeabilization, block and washing. Immune fluorescence images of the nuclear translocation of nuclear factor kappa B (NFkB)-p65 and NFkB-p52 in response to $100 \mathrm{ng} / \mathrm{ml} \mathrm{TNFa}$ and $1 \mu \mathrm{g} / \mathrm{ml}$ agonistic anti-LT $\beta R$ antibody stimulation were examined by Zeiss photomicroscope equipped for fluorescence microscopy.

\section{Results}

FRC affected T cell survival against drug cytotoxicity

FDC affects B cell biology via the promotion of germinal center B cell survival by providing survival soluble factors including cytokines, and chemokines via tissue fluid [29]. Based on this phenomenon, we hypothesized that these FRC also have a regulatory effect on $\mathrm{T}$ cell biological behavior. Thus, in vitro co-culture of $\mathrm{T}$ cells in the presence of FRC monolayer made onto cell culture dish to investigate the influence of FRC in involvement with $\mathrm{T}$ cell biological actions was performed. First of all, we analyzed the survival or proliferation of $\mathrm{T}$ cells as one of $\mathrm{T}$ cell biological markers via MTS assay in this culture system with anti-cancer agent, Dox. The presence of Dox in this culture did not disturb the FRC viability pattern (Fig. 1). In situation of $\mathrm{T}$ cell survival with or without Dox, Dox affected less $\mathrm{T}$ cell survival during the $24 \mathrm{~h}$ of $\mathrm{T}$ cell culture (Fig. 1). Additional $\mathrm{T}$ cell culture in the presence or in the absence of FRC monolayer resulted in further $\mathrm{T}$ cellular proliferation (Fig. 1). In contrast, as shown in Fig. 1, the addition of Dox in FRC+T cell co-culture resulted in the decrease of $\mathrm{T}$ cell survival. Collectively, FRC affected $\mathrm{T}$ cell biology in terms of $\mathrm{T}$ cell survival, especially.

$B$ cell lymphoma (Bcl)-xL was involved in survival of $\mathrm{T}$ cell against Dox

To understand the phenomenon underlying $\mathrm{T}$ cell survival enhanced in the presence or absence of FRC monolayer against Dox (Fig. 1), we thought that FRC secrete soluble survival factors into cell culture sup similar to the secretion of FRC into tissue fluid in viva Thus, it is possible to contain soluble survival factors in FRC culture sup. The enhancement of $\mathrm{T}$ cell survival was regulated by the expression of pro-survival Bcl-2 family protein, one of cell survival factors [19]. Thus, FRC culture sup was prepared as description in 


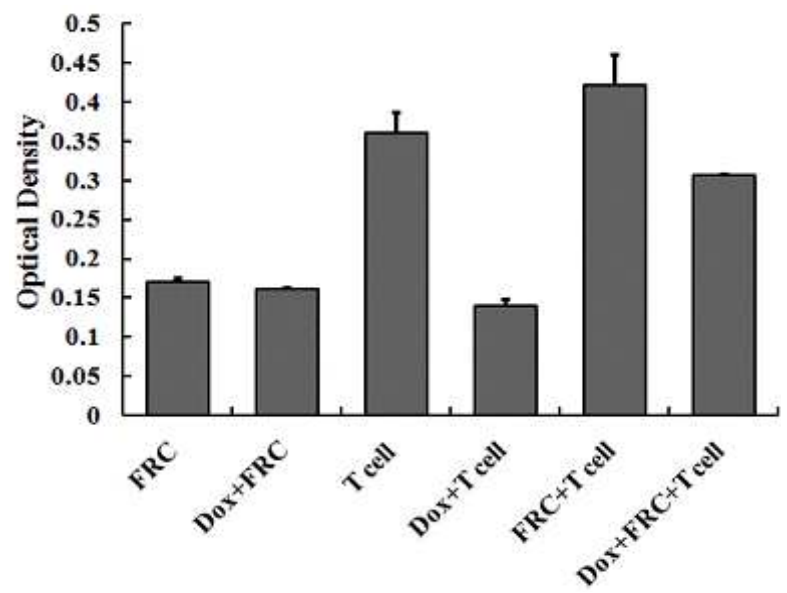

Fig. 1. Effect of co-cultured FRC on drug cytotoxicity in T cells. Confluent FRC monolayer was made onto $6 \phi$ dish and cocultured with $100 \mathrm{\mu g} / \mathrm{ml}$ Dox-treated CD4+ EL4 T cells $\left(1 \times 10^{6}\right.$ cells/dish) in RPMI640 medium supplement with $10 \%$ FCS for $24 \mathrm{~h}$. After incubation, the unbound or bound $\mathrm{T}$ cells were removed by washing with PBS, and then, culture sup including the FRCs were collected and cell viability was measured by MTS assay. The data shown represent three independent experiments and are represented as the mean \pm S.D.

material and method to investigate the effect of FRC sup about $\mathrm{T}$ cell survival with the involvement of the cell survival protein Bcl-xL. As shown in Fig. 2, FRC sup strongly induced increased expression of Bcl-xL in comparison with $\mathrm{T}$ cell as a negative control. Dox+FRC sup induced an increase in Bcl-xL expression, but only Dox-treated $\mathrm{T}$ cell decreased expression of Bcl-xL (Fig. 2). It suggests that FRC culture media contain soluble factors derived from FRC in influencing Bcl-xL expression.

Morphological alteration of FRC monolayer $\mathrm{CO}^{-}$ cultured with $\mathrm{T}$ cells

To directly probe the cell biological change such as FRC shape, $\mathrm{T}$ cell adhesion against FRC monolayer, FRC was co-cultured with $\mathrm{T}$ cells and observed under fluorescence microscope with rodamine phalloidin staining. As shown in Fig. 3, this co-culture resulted in large-scale structural rearrangements in the actin cytoskeleton as well as global changes of cell shape. In addition, several $\mathrm{T}$ cells were attached to FRC (Fig. 3). Moreover, actin stress fibers were disrupted in co-cultured FRC and F-actin was diminished in FRC co-cultured with $\mathrm{T}$ cell (Fig. 3). This finding suggests that FRC physically interact with $\mathrm{T}$ cell and is involved in $\mathrm{T}$ cell biology.

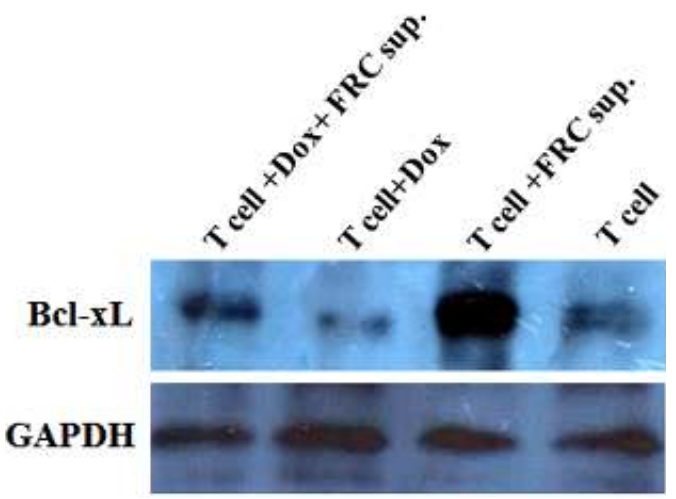

Fig. 2. Effect of FRC sup on Bcl-xL expression in T cells. FRC $\left(5 \times 10^{6}\right.$ cells) was grown on $6 \phi$ dish plate for $24 \mathrm{~h}$. Culture sup of the FRCs were collected, filtrated, and stored until experiments. And protein concentration of sup was measured by BCA method. T cells $\left(5 \times 10^{6}\right.$ cells $)$ were pretreated with FRC sup $(100 \mathrm{ng} / \mathrm{ml})$ and incubated for $1 \mathrm{~h}$, and followed by further incubation for $24 \mathrm{~h}$ in the presence or absence of FRC sup and Dox $(100 \mu \mathrm{g} / \mathrm{ml})$. The expression degree of Bcl-xL was detected by Western blot. GAPDH was used to demonstrate equal loading of lysates.

Expression pattern of adhesion molecular ICAM-1 in FRC co-cultured with $T$ cell

ICAM-1 plays an important role in firm arrest to the cell-cell interaction via suitable ligands/ICAM-1. Activated leukocytes are adhered firmly, initiate transendothelial migration as well as the binding between ICAM-1 and lymphocyte function-associated antigen (LFA)-1 facilitates close contact between the antigen presenting cell and $\mathrm{T}$ cells for the immunological synapse formation $[9,25]$. Moreover, ligation of LFA-1 and ICAM-1 is important in a variety of cellular events including Ag-specific T cell activation, $\mathrm{T}$ cell migration and antigen scanning in LN [12]. sICMA-1 serves as a counter-receptor or competitor for the LFA-1 for the cell physiological regulation [31]. As shown Fig 3, when FRC and $\mathrm{T}$ cell were co-cultured, $\mathrm{T}$ cell was adhered to FRC monolayer. Thus, we investigated the expression of ICAM-1 in FRC cocultured with T cell. FRC expressed mICAM-1 and sICAM-1. mICAM-1 slightly increased by day-dependent manner, however, sICAM-1 drastically increased by day-dependent manner (Fig. 4). These findings suggest that FRC has the ability to provide cooperative interaction and cell biological function to $\mathrm{T}$ cell.

Gene alteration in FRC by agonistic anti-LTßR
antibody and TNFa

shown in Fig. 3 and 4, morphological change, stress fiber 

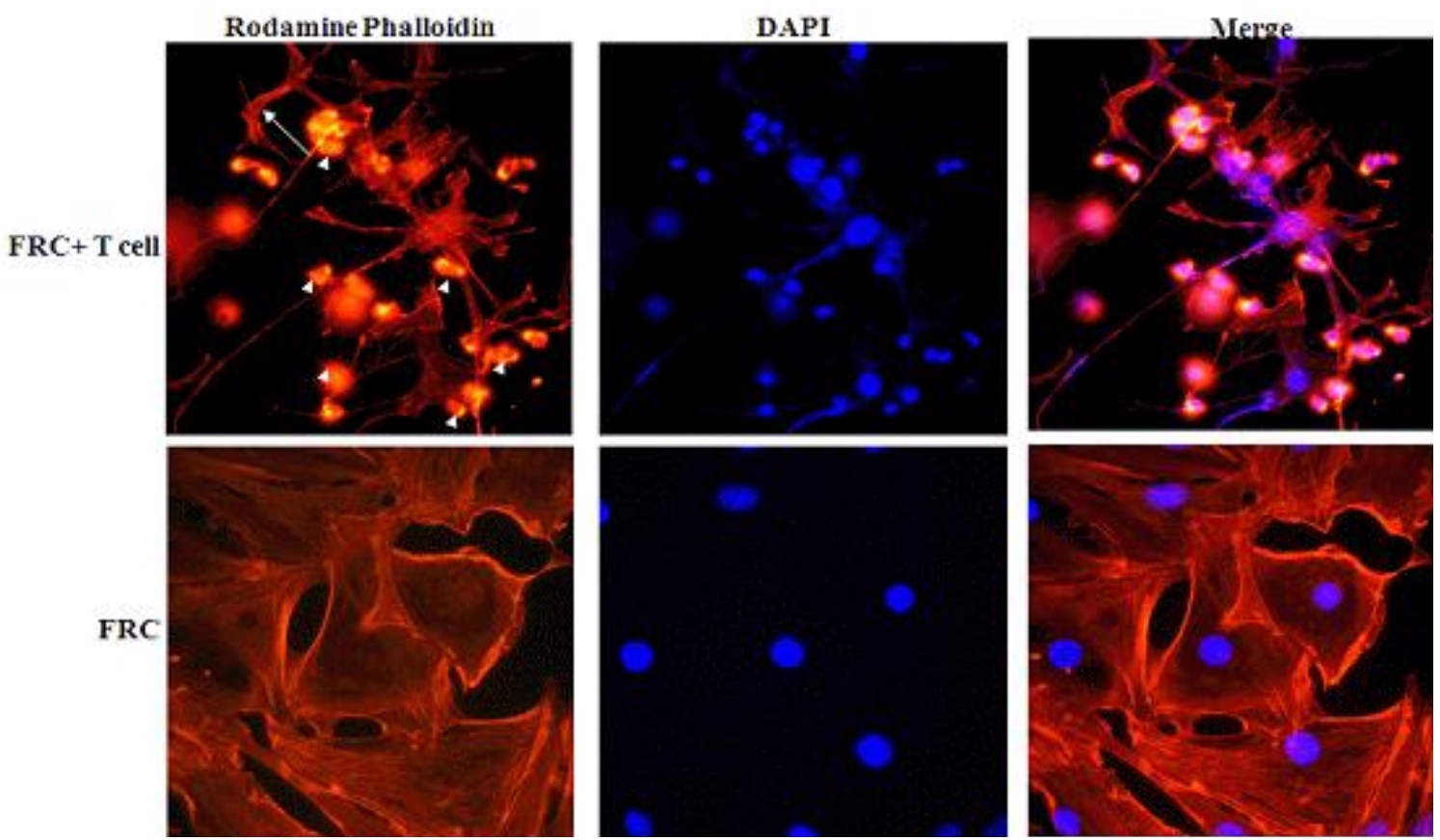

Fig. 3. Alteration of cell shape and stress fibers in FRC using a fluorescence microscopy. FRC monolayers (arrow) on chamber slides were cocultured with CD4+ EL4 T cells (arrow head) for $24 \mathrm{~h}$. Cells were stained with rodamine phalliodin for changes in F-actin distribution after fixation and washing, and examined by Zeiss photomicroscope equipped for fluorescence microscopy. Nuclear was stained with DAPI.

alteration, and increased sICAM-1 production were detected in FRC co-cultured with T cell. Accumulation of lymphocytes induces alteration of FRC such that they produce chemokines for further lymphocyte attraction via the secretion of TNFa (or related cytokines) and likely also via direct contacts mediated by adhesion molecules and LTa1ß2 [14]. TNF family cytokines including the membrane heterotrimeric form of LTa1 32 are important for lymphoid tissue archi-

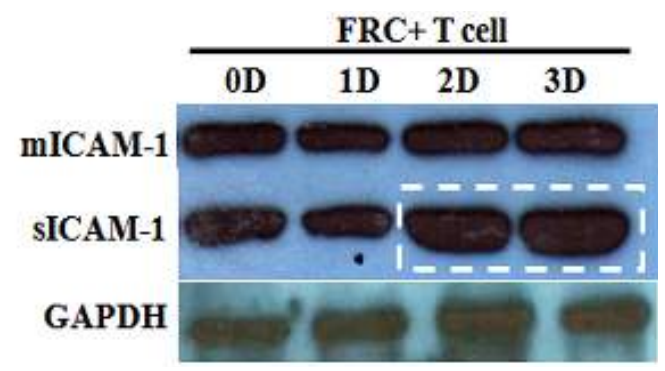

Fig. 4. Effect of $\mathrm{T}$ cell coculture on ICAM-1 expression in FRCs. FRC $\left(5 \times 10^{6}\right.$ cells $)$ was grown on $6 \phi$ dish plate for indicated time. $\mathrm{T}$ cells $\left(5 \times 10^{6}\right.$ cells $)$ were coculture with FRC. After coculture, T cells were removed out by washing with PBS. Cell was lyzed with RIPA buffer and protein concentration of FRC lysate was measured by BCA method. The expression degree of mICAM-1 and sICAM-1 was detected by Western blot. GAPDH was used to demonstrate equal loading of lysates. tecture and organogenesis [20]. Thus, it allows for us to examine the roles of these mediators in the gene alteration of FRC. We compared the panel of transcripts whose expression was altered in TNFa-treated and agonistic anti-LT $\beta$ $\mathrm{R}$ antibody-treated FRC compared to normal FRC. Our results demonstrate that TNFa in FRC $(p<0.05)$ affected the expression of 723 identified transcripts regulated minimally by greater than or equal to a 2-fold change to total probe \# 39,429. Of the identified regulated genes, 902 were down-regulated. In addition, agonistic anti-LTßR antibody affected the expression of 391 transcripts regulated minimally by greater than or equal to a 2-fold change to total probe \# 39,429 and 496 genes were down-regulated. Chemokines lead to leukocyte homing and are implicated actively in immune reaction. Metalo matrix proteinase (MMP) functions the remodel of ECM and digests membrane bound chemokines or adhesion molecules to facilitate the function of T lymphocyte in LN. Thus, we analyzed the expression pattern of these factors in gene chip results. Of the regulated genes, the following was known to affect leukocyte homing and $\mathrm{T}$ cell biological function (Table 1). Soluble factors described in table 1, 2 were related to T cell response. These results indicate that FRC was tightly connected with $\mathrm{T}$ cell rather than $\mathrm{B}$ cell. 
Table 1. Chemokine and cytokine transcripts modulated in FRCs by TNFa exposure

\begin{tabular}{|c|c|c|c|c|}
\hline Systematic & GeneSymbol & Normalization $^{\dagger}$ & Regulation* & Remark \\
\hline A_51_P184484 & Mmp13 & 93.943954 & UP & $\mathrm{T}$ cell mediated tissue remodelling \\
\hline A_51_P255699 & Mmp3 & 51.54251 & UP & $\begin{array}{l}\text { Extracellular matrix remodeling invovlved in } \mathrm{CD} 4+\mathrm{T} \text { lymphocyte } \\
\text { migration }\end{array}$ \\
\hline A_52_P638459 & Ccl5 & 28.396307 & UP & $\begin{array}{l}\text { Directional movement induction of activated CXCR3 and CCR5 } \\
\text { bearing } \mathrm{T} \text { cells }\end{array}$ \\
\hline A_51_P363187 & Cxcl1 & 24.750534 & UP & Effector CD8 $\mathrm{T}$ cell recruitment \\
\hline A_51_P120830 & Mmp10 & 20.856514 & UP & $\begin{array}{l}\text { Degradation of various components of the extracellular matrix; } \\
\text { Activation of ICAM-1/LFA-1-mediated intercellular contact }\end{array}$ \\
\hline A_55_P1990032 & Cxcl5 & 16.097998 & UP & Neutrophil attractant \\
\hline A_52_P99888 & Cxcl16 & 14.880662 & UP & $\begin{array}{l}\text { Transmembrane chemokine; CD8 }+\mathrm{T} \text { cell attraction and adhesion } \\
\text { in LN }\end{array}$ \\
\hline A_55_P2016462 & Cxcl10 & 8.553003 & UP & Chemotaxis of CXCR3+ Th1 and Tc1 \\
\hline A_51_P464703 & $\mathrm{Ccl} 8$ & 7.2886925 & UP & CD4(+) T lymphocytes homing \\
\hline A_52_P232813 & $\mathrm{Cxcl} 3$ & 5.551653 & UP & Inhibition of $\mathrm{T}$ cell proliferation \\
\hline A_52_P613241 & Icam1 & 5.525103 & UP & Cell adhesion and chemotaxis of $\mathrm{T}$ cell \\
\hline A_55_P1961451 & Adamts7 & 5.5199876 & UP & $\begin{array}{l}\text { Extracellular matrix (ECM)-degrading proteinases in VSMC } \\
\text { migration }\end{array}$ \\
\hline A_51_P231320 & Mmp8 & 5.5022626 & UP & Collagenases, macrophage chemoattractant, Inflammation \\
\hline A_52_P507214 & Mmp9 & 4.4453382 & UP & Up-regulated antigen-specific T-cell responses \\
\hline A_52_P52618 & Csf2rb & 4.142702 & UP & Regulation of Th2 immunity \\
\hline A_51_P331752 & Ccl11 & 3.4064958 & UP & Regulation of Th2 environment \\
\hline A_51_P286737 & $\mathrm{Ccl} 2$ & 2.0796976 & UP & monocyte chemoattractant protein \\
\hline A_55_P2068723 & $\mathrm{Ccl} 27 \mathrm{a}$ & 0.3715961 & DOWN & $\begin{array}{l}\text { inflammatory } \mathrm{T} \text { cell response; Chemoattractant for Th-2 type } \\
\text { T-cells }\end{array}$ \\
\hline A_51_P196925 & Cx3cl1 & 0.3694497 & DOWN & Integrin-independent leukocyte adhesion \\
\hline A_51_P114462 & Ccl17 & 0.2876406 & DOWN & Th2-attracting chemokines \\
\hline
\end{tabular}

${ }^{\dagger}$ Normalization was the ratio between TNFa treated sample value vs control value.

*Regulation was decided by normalized values (i.e., values above 2 fold) as UP regulation and (values below 0.5 fold) as DOWN regulation.

Activation of $\mathrm{NFkB}$ pathway in TNFa-treated and agonistic anti-LTRR antibody-treated FRC

mediators such as chemokines and MMPs modulate immune system through activation of the transcription factor NFkB pathway $[3,27]$. Furthermore, we investigated the expression of several chemokines and MMPs in FRC treated with TNFa and agonistic anti-LTßR antibody (Table 1, 2). TNFa elicits triggers signal cascade via its receptors (TNFRI and TNFRII) toward RleA (p65)-p50 complex (p105) (canonical pathway). In contrast, LTa1ß2 activates a distinct signaling pathway toward RelB-p52 (p100) complex (noncanonical pathway) via LTßR [5, 30]. Thus, NFkB activation mechanism was investigated via immune-staining in FRC treated with TNFa and agonistic anti-LT $\beta R$ antibody. In resting cells, NFkB was located in the cytoplasm, how- ever, NFkB was activated and translocated into nuclear when TNFa was treated in FRC (Fig. 5A). In contrast, strikingly, we observed that p52 proteolyzed from p100, counterparter of RelB of non-canonical NFkB pathway, was accumulated in peripheral nucleus when agonistic anti-LTßR antibody was treated in FRC (Fig. 5B). The fact that FRC could transcribe chemokines and MMPs despite their inability to translocate p52 suggested that other NFKB family members may regulate LTa1 $\beta 2$-LT $\beta R$ signaling pathway.

\section{Discussion}

The three dimensional architecture of $\mathrm{LN}$ is thought to optimize antigen correction and presentation to naive circulating lymphocytes and allow for clonal selection and rapid 
Table 2. Chemokine and cytokine transcripts modulated in FRCs by agonistic anti LTßR antibody exposure

\begin{tabular}{|c|c|c|c|c|}
\hline Systematic & GeneSymbol & Normalization $^{\dagger}$ & Regulation* & Remark \\
\hline A_52_P99888 & Cxcl16 & 14.948073 & UP & $\mathrm{T}$ cell migration \\
\hline A_52_P507214 & Mmp9 & 9.049398 & UP & Up-regulated antigen-specific T-cell responses \\
\hline A_51_P120830 & Mmp10 & 8.330407 & UP & $\begin{array}{l}\text { Degradation of various components of the extracellular matrix; } \\
\text { Activation of ICAM-1/LFA-1-mediated intercellular contact }\end{array}$ \\
\hline A_51_P255699 & Mmp3 & 5.987079 & UP & $\begin{array}{l}\text { Extracellular matrix remodeling invovlved in } \mathrm{CD} 4+\mathrm{T} \text { lymphocyte } \\
\text { migration }\end{array}$ \\
\hline A_51_P331752 & Ccl11 & 5.610748 & UP & Angiogenesis, Migration of activated T cell \\
\hline A_52_P52618 & Csf2rb & 5.2937036 & UP & Regulation of Th2 immunity \\
\hline A_51_P464703 & $\mathrm{Ccl} 8$ & 4.5239396 & UP & Inflammation, Development of DC \\
\hline A_52_P638459 & $\mathrm{Ccl} 5$ & 4.4313483 & UP & $\mathrm{T}$ cell activation \\
\hline A_55_P2016462 & Cxcl10 & 3.1940744 & UP & Chronic inflammation, monocyte, $\mathrm{T}$ cell, NK cell chemotaxis \\
\hline A_51_P363187 & Cxcl1 & 2.6172688 & UP & Neutrophil migration, $\mathrm{T}$ cell migration \\
\hline A_55_P1990032 & Cxcl5 & 2.500141 & UP & $\begin{array}{l}\text { Hematopoietic stem cell migration, Leukocyte recruitment, } \\
\text { Neutrophil homeostasis }\end{array}$ \\
\hline
\end{tabular}

${ }^{\dagger}$ Normalization was the ratio between TNFa treated sample value vs control value.

*Regulation was decided by normalized values (i.e., values above 2 fold) as UP regulation.
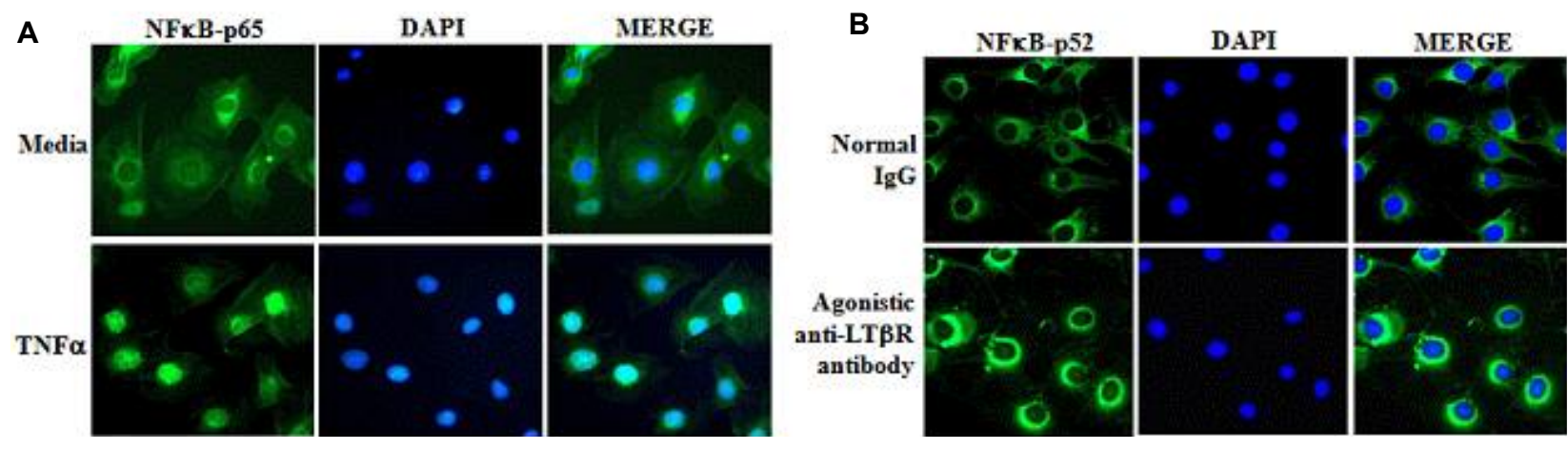

Fig. 5. Involvement of canonical and noncanonical pathway of NFkB in FRC. FRC monolayers on chamber slides were cultured. Cells were stained with anti-p65 antibody for canonical pathway (A) and anti-p52 antibody for noncanonical pathway (B) after fixation, permeabilization, block and washing. Immune fluorescense images of the nuclear translocation of NFkB-p65 and NFkB-p52 in response to $100 \mathrm{ng} / \mathrm{ml} \mathrm{TNFa}$ and $1 \mathrm{\mu g} / \mathrm{ml}$ agonistic anti-LTßR antibody stimulation for $6 \mathrm{~h}$ in FRC were examined by examined by Zeiss photomicroscope equipped for fluorescence microscopy.

cell proliferation of antigen-specific $\mathrm{T}$ and cognated B lymphocytes, as well as their differentiation into effector cells. To make these processes more efficient LN are zoned into structurally distinct microparts: The B zone (follicle or outer cortex), $\mathrm{T}$ zone (paracortex), medulla zone and entry and exit zones. In this study, we investigated the directional cell biological involvement between FRC and $\mathrm{T}$ cell for the cross-talk, each other. FRC resides in $\mathrm{T}$ zones and constitutively secrete the chemokines to attract and retain $\mathrm{T}$ cells [21, 28]. So far, main role of FRC has been addressed to make network, which acts as physical migration road during $\mathrm{T}$ cell migration $[13,21]$. While FRC form the structural back bone of the $\mathrm{T}$ cell rich zones in $\mathrm{LN}$, but also actively influ- ence the $\mathrm{T}$ cell biological situation. FRC are the major source of constitutive IL-7 expression in LN and thereby regulate the fitness, survival and homeostasis of naive recirculating T cells $[7,10]$. As shown in Fig. 1, FRC co-cultured with $\mathrm{T}$ cells inhibited $\mathrm{T}$ cell apoptosis against Dox. Thus, the effect of $\mathrm{T}$ cell anti-apoptosis against Dox may be related to action of IL-7 secreted from FRC. We demonstrated the expression of $B C l-x L$ was significantly increased in $\mathrm{T}$ cells treated with FRC sup (Fig. 2). The expression of BCl-2 family genes is important for the survival of $\mathrm{T}$ cells [19]. Recently, $\mathrm{T}$ cells in LN were significantly decreased in signal transducer and activator of transcription 3 (Stat3)-deficient mice [15]. Expression of the cell survival genes $B C l-2$ and $B C l x L$ was 
markedly decreased in the T cell - specific Stat3-deleted mice [15]. Stat3, as a key regulator of Bcl-2 family genes, promotes the proliferation of activated $\mathrm{T}$ cells and regulates the lifespan of $\mathrm{T}$ lymphocytes. Stat 3 regulates $\mathrm{T}$ cell homeostasis and survival by maintaining the required naïve T-cell population in LN [15]. It suggests that Stat3 helps to maintain the T-cell pool in the resting condition by promoting the expression of $B \mathrm{Cl}-2$ family genes. Therefore, cell survival factors such as survivin, Stat3 and cleaved caspase-3 protein levels must be checked by further study. Overnight incubation of FRC with $\mathrm{T}$ cells led to a morphological change and disruption of stress fiber. It seems likely that unknown factors produced by $\mathrm{T}$ cells are sensed by FRC leading to alteration induction. The signals exchanged between FRC and $\mathrm{T}$ cells leading to alteration induction is unclear. However, within the first $20 \mathrm{~h}$ upon TCR triggering, T cells produce a first wave of TNFa cytokines. It seems likely that TNFa produced by $\mathrm{T}$ cells are sensed by FRC leading to change induction. We detected that FRC cocultured with $\mathrm{T}$ cell expressed mICAM-1 and sICAM-1 day-dependent manner (Fig. 4). For the firm and physical attachment for the interaction between $\mathrm{T}$ cells and other cells, the contact between $\mathrm{T}$ cells and other cells is strengthened by additional interactions between the integrin LFA-1 on the T cell surface and the ICAM-1 on other cell surface [26]. sICAM-1 is constitutively expressed or is inducible on the cell surface of different cell lines [31]. sICAM-1 binding to LFA is capable of inhibiting lymphocyte attachment to endothelial cells [31]. These findings suggest the concept that FRC has the ability to provide cooperative response for the cell biological role. Detailed functions of mICAM- 1 and sICAM- 1 between FRC and $\mathrm{T}$ cell remain to be elucidated. Members of TNF family cytokines including the membrane heterotrimeric form of LT a1ß2 of T cell are important for lymphoid tissue architecture and organogenesis [14]. Thus, we examined the roles of these mediators in the FRC gene alteration. Stimulation of FRCs with TNFa and commercially well-known agonistic anti-LT $\beta$ $\mathrm{R}$ antibody raised against the extracellular part of LTBR mimic receptor are able to induce downstream signals [14]. Many cytokines and MMPs were produced by FRC in table1, 2, and the FRC-derived these signals are thought to stimulate $\mathrm{T}$ cell behavior onto FRC monolayer. TNFa uses its receptors with TNFRI and TNFRII toward RelA-p50 (NFkB-canonical pathway). In contrast, LTa1 $\beta 2$ triggers a distinct signaling pathway toward RelB-p52 (p100) (NFkB-noncanonical pathway) via LT $\beta R[21,28]$. NFkB has multiple roles in the im- mune system, both in the development, differentiation, and survival regulation of its effector cells, as well as in the dynamic regulation of local and systemic immune activity. TNF a was able to trigger the nuclear translocation of RelA, however, agonistic anti-LT $\beta R$ antibody was able to trigger the peripheral nuclear translocation of p52, RelB counterpart (Fig. 5). Five mammalian NFkB genes give rise to five transcription factor proteins, RelA, cRel, RelB, p50, and p52. Five NFKB polypeptides can form 15 transcription factors through homo- and hetero-dimerization [8]. In a given cell, a subset of dimers may be present, depending on the cell stage, and conditioning by additional cues in case of agonistic anti-LTßR antibody. In this research we discussed our findings which suggest that FRC in $\mathrm{T}$ zone are not simple scaffolding cells, but actively influence $\mathrm{T}$ cell biology.

\section{Acknowledgments}

This research was supported by Basic Science Research Program through the National Research Foundation of Korea (NRF) funded by the Ministry of Education, Science and Technology (Grant \#: NRF-2011-0011128).

\section{References}

1. Anderson, A. O. and Anderson, N. D. 1975. Studies on the structure and permeability of the microvasculature in normal rat lymph nodes. Am J Pathol 80, 387-418.

2. Cory, A. H., Owen, T. C., Barltrop, J. A. and Cory, J. G. 1991. Use of an aqueous soluble tetrazolium/formazan assay for cell growth assays in culture. Cancer Commun 3, 207-212.

3. Del Prete, A., Allavena, P., Santoro, G., Fumarulo, R., Corsi, M. M. and Mantovani, A. 2011. Molecular pathways in cancer-related inflammation. Biochem Med (Zagreb) 21, 264-275.

4. Gao, X., Deeb, D., Hao, J., Liu, Y., Arbab, A. S., Dulchavsky, S. A. and Gautam, S. C. 2010. Synthetic triterpenoids inhibit growth, induce apoptosis and suppress pro-survival Akt, mTOR and NF-\{kappa\}B signaling proteins in colorectal cancer cells. Anticancer Res 30, 785-792.

5. Gommerman, J. L. and Browning, J. L. 2003. Lymphotoxin/ LIGHT, lymphoid microenvironments and autoimmune disease. Nat Rev Immunol 3, 642-655.

6. Gretz, J. E., Anderson, A. O. and Shaw, S. 1997. Cords, channels, corridors and conduits: critical architectural elements facilitating cell interactions in the lymph node cortex. Immunol Rev 156, 11-24.

7. Hara, T., Shitara, S., Imai, K., Miyachi, H., Kitano, S., Yao, H., Tani-Ichi, S. and Ikuta, K. 2012. Identification of IL-7-producing cells in primary and secondary lymphoid or- 
gans using IL-7-GFP knock-in mice. J Immunol 189, 15771584.

8. Hoffmann, A. and Baltimore, D. 2006. Circuitry of nuclear factor kappaB signaling. Immunol Rev 210, 171-186.

9. Hossain, M., Qadri, S. M., Su, Y. and Liu, L. 2013. ICAM-1mediated leukocyte adhesion is critical for the activation of endothelial LSP1. Am J Physiol Cell Physiol 304, 895-904.

10. Huang, H. Y. and Luther, S. A. 2012. Expression and function of interleukin-7 in secondary and tertiarylymphoidorgans. Sem Immunol 24, 175-189.

11. Kaldjian, E. P., Gretz, J. E., Anderson, A. O., Shi, Y. and Shaw, S. 2001. Spatial and molecular organization of lymph node $\mathrm{T}$ cell cortex: a labyrinthine cavity bounded by an epithelium-like monolayer of fibroblastic reticular cells anchored to basement membranelike extracellular matrix. Int Immunol 13, 1243-1253.

12. Katakai, T., Habiro, K. and Kinashi, T. 2013. Dendritic cells regulate high-speed interstitial $\mathrm{T}$ cell migration in the lymph node via LFA-1/ICAM-1. I Immunol 191, 1188-1199.

13. Katakai, T., Hara, T., Lee, J. H., Gonda, H., Sugai, M. and Shimizu, A. 2004. A novel reticular stromal structure in lymph node cortex: an immuno-platform for interactions among dendritic cells, $\mathrm{T}$ cells and B cells. Int Immunol 16, 1133-1142.

14. Katakai, T., Hara, T., Sugai, M., Gonda, H. and Shimizu, A. 2004. Lymph node fibroblastic reticular cells construct the stromal reticulum via contact with lymphocytes. J Exp Med 200, 783-795.

15. Lee, J. K., Won, C., Yi, E. H., Seok, S. H., Kim, M. H., Kim, S. J., Chung, M. H., Lee, H. G., Ikuta, K. and Ye, S. K. 2013. Stat3 contributes to T-cell homeostasis by regulating prosurvival Bcl-2 family genes. Immunology doi:10.1111/imm. 12133.

16. Lukacs-Kornek, V., Malhotra, D., Fletcher, A. L., Acton, S. E., Elpek, K. G., Tayalia, P., Collier, A. R. and Turley, S. J. 2011. Regulated release of nitric oxide by nonhematopoietic stroma controls expansion of the activated $\mathrm{T}$ cell pool in lymph nodes. Nat Immunol 12, 1096-1104.

17. Malhotra, D., Fletcher, A. L., Astarita, J., Lukacs-Kornek, V., Tayalia, P., Gonzalez, S. F., Elpek, K. G., Chang, S. K., Knoblich, K., Hemler, M. E., Brenner, M. B., Carroll, M. C., Mooney, D. J. and Turley, S. J. 2012. Transcriptional profiling of stroma from inflamed and resting lymph nodes defines immunological hallmarks. Nat Immunol 13, 499-510.

18. Malhotra, D., Fletcher, A. L. and Turley, S. J. 2013. Stromal and hematopoietic cells in secondary lymphoid organs: partners in immunity. Immunol Rev 251, 160-176.

19. Maraskovsky, E., O’Reilly, L. A., Teepe, M., Corcoran, L. M., Peschon, J. J. and Strasser, A. 1997. Bcl-2 can rescue T lymphocyte development in interleukin-7 receptor-deficient mice but not in mutant rag-1-/- mice. Cell 89, 1011-1019.

20. Mebius, R. E. 2003. Organogenesis of lymphoid tissues. Nat Rev Immunol 3, 292-303.

21. Mueller, S. N. and Germain, R. N. 2009. Stromal cell contributions to the homeostasis and functionality of the immune system. Nat Rev Immunol 9, 618-629.

22. Riss, T. L. and Moravec, R. A. 1992. Comparison of MTT, XTT, and a novel tetrazolium compound for MTS for in vitro proliferation and chemosensitivity assays. Mol Biol Cell (Suppl.) 3, 184a.

23. Roozendaal, R., Mebius, R. E. and Kraal, G. 2008. The conduit system of the lymph node. Int Immunol 20, 1483-1487.

24. Sixt, M., Kanazawa, N., Selg, M., Samson, T., Roos, G., Reinhardt, D. P., Pabst, R., Lutz, M. B. and Sorokin, L. 2005. The conduit system transports soluble antigens from the afferent lymph to resident dendritic cells in the $\mathrm{T}$ cell area of the lymph node. Immunity 22, 19-29.

25. Springer, T. A. and Dustin, M. L. 2012. Integrin inside-out signaling and the immunological synapse. Curr Opin Cell Biol 24, 107-115.

26. Stanley, P., Tooze, S. and Hogg, N. 2012. A role for Rap2 in recycling the extended conformation of LFA-1 during $\mathrm{T}$ cell migration. Biol Open 1, 1161-1168.

27. Thompson, W. L. and Van Eldik, L. J. 2009. Inflammatory cytokines stimulate the chemokines CCL2/MCP-1 and CCL7/MCP-3 through NFkBand MAPK dependent pathways in rat astrocytes [corrected]. Brain Res 1287, 47-57.

28. Turley, S. J., Fletcher, A. L. and Elpek, K. G. 2010. The stromal and haematopoietic antigen-presenting cells that reside in secondary lymphoid organs. Nat ReV Immunol 10, 813-825.

29. Wang, X., Cho, B., Suzuki, K., Xu, Y., Green, J. A., An, J. and Cyster, J. G. 2011. Follicular dendritic cells help establish follicle identity and promote B cell retention in germinal centers. J Exp Med 208, 2497-2510.

30. Weih, F. and Caamano, J. 2003. Regulation of secondary lymphoid organ development by the nuclear factor- $\mathrm{kB}$ signal transduction pathway. Immunol Rev 195, 91-105.

31. Witkowska, A. M. and Borawska, M. H. 2004. Soluble intercellular adhesion molecule-1 (sICAM-1): an overview. Eur Cytokine Netw 15, 91-98. 
초록 : T세포와 양방향 작용을 통한 마우스 림프절로부터 분리된 fibroblastic reticular cell의 기능적 분석

박성희 $^{1} \cdot$ 이종환 ${ }^{1,2}$

('동의대학교 생명공학과, ${ }^{2}$ 동의대학교 스마트바이오헬스학과)

Fibroblastic reticular cells (FRC)는 림프절 $\mathrm{T}$ 세포 지역에 구조적 골격 형성을 하며 유입 $\mathrm{T}$ 세포의 안내길을 제공한다. FRC는 림프절에서 T세포 생물학 발달에 기여한다. 따라서, 이것이 FRC와 T세포 사이에서 $\mathrm{FRC}$ 의 세포생 물학적 근본 기능을 알아보게 하였다. FRC 배양 상등액은 T세포 사멸을 저해하였다. FRC 상등액은 doxorubicin에 대하여 T세포에 Bcl-xL의 발현을 증가시켰다. $\mathrm{FRC}$ 와 T세포의 공배양은 $\mathrm{FRC}$ 의 액틴 골격의 변화와 형태적 변화를 유도하였다. 또한, $\mathrm{FRC}$ 와 T세포의 공배양은 T 세포가 FRC 단일층에 부착하는 결과를 유도하였고 막결합형 intercellular adhesion molecule (ICAM)-1 단백질의 발현은 약간 증가한 반면 용해성 ICAM-1 (sICAM-1) 발현은 시간 의존적으로 드라마틱하게 증가하였다. $\mathrm{FRC}$ 는 $\mathrm{T}$ 세포에 의해 분비되는 tumor necrosis factor (TNF) 패밀리들에 의해 CCL5, CXCL1, CXCL5, CXCL16, CCL8, CXCL13와 같은 케모카인들과 ICAM-1 그리고 MMPs의 발현량을 증가시켰다. TNFa가 FRC에 처리 되었을때 NFkB canonical pathway의 RelA는 핵으로 전좌 되었지만, agonistic anti-LT $\beta R$ antibody로 처리된 FRC에서 non-canonical NFkB pathway의 RelB의 카운터 파트너인 p100의 분해산물 $\mathrm{p} 52$ 는 핵주변부로 축적되었다. 결론적으로 FRC는 FRC와 T세포 양방향 협력을 통해 T세포 생물학적 기능을 증진한 다. 이러한 상호협력 관계는 면역반응 동안 조직의 통합성과 기능을 유지하는데 도움을 줄 것으로 사료된다. 